Cereals 


\section{HANDBOOK OF PLANT BREEDING}

Editors-in-Chief:

JAIME PROHENS, Universidad Politecnica de Valencia, Valencia, Spain FERNANDO NUEZ, Universidad Politecnica de Valencia, Valencia, Spain MARCELO J. CARENA, North Dakota State University, Fargo, ND, USA

Volume 1

Vegetables I: Asteraceae, Brassicaceae, Chenopodicaceae, and Cucurbitaceae Edited by Jaime Prohens and Fernando Nuez

Volume 2

Vegetables II: Fabaceae, Liliaceae, Solanaceae and Umbelliferae

Edited by Jaime Prohens and Fernando Nuez

Volume 3

Cereals

Edited by Marcelo J. Carena 
Marcelo J. Carena

Editor

Cereals

祭 Springer 
Editor

Prof. Dr. Marcelo J. Carena

North Dakota State University

Corn Breeding \& Genetics

Dept. of Plant Sciences

Dept \#7670

374D Loftsgard Hall

Fargo ND 58108-6050

USA

marcelo.carena@ndsu.edu

ISBN 978-0-387-72294-8

e-ISBN 978-0-387-72297-9

DOI: $10.1007 / 978-0-387-72297-9$

\section{Library of Congress Control Number: PCN Applied for}

(C) Springer Science + Business Media, LLC 2009

This work is subject to copyright. All rights are reserved, whether the whole or part of the material is concerned, specifically the rights of translation, reprinting, reuse of illustrations, recitation, broadcasting, reproduction on microfilm or in any other way, and storage in data banks. Duplication of this publication or parts thereof is permitted only under the provisions of the German Copyright Law of September 9, 1965, in its current version, and permissions for use must always be obtained from Springer-Verlag. Violations are liable for prosecution under the German Copyright Law.

The use of general descriptive names, registered names, trademarks, etc. in this publication does not imply, even in the absence of a specific statement, that such names are exempt from the relevant protective laws and regulations and therefore free for general use.

Printed on acid-free paper.

987654321

springer.com 


\section{Preface}

Plant breeding is a discipline that has evolved with the development of human societies. Similar to the rapid changes in other disciplines during the twentieth century, plant breeding has changed from selection based on the phenotype of individuals to selection based on the information derived at the deoxyribonucleic acid (DNA) level in molecular genetic laboratories and data from replicated field experiments. The initial beginnings of plant breeding occurred when humans made the transition from a nomadic hunter-gatherer lifestyle to the development of communities, colonies, tribes, and civilizations. The more sedentary lifestyle required that adequate food supplies (both plant and animal) were available within the immediate surrounding areas. The plants available within the immediate areas became very important to sustain the food, fuel, fiber, and feed needs of the local settlements. Hence, the greater the grain and forage yields of the native plants, the greater the sustainability of the needs of the local settlements. They recognized the relative importance of some plant species that could meet the needs of the settlements and practiced selection of individual plants that had greater grain and/or forage yields. Seed was saved from desirable plants to perpetuate the plants in the next growing season. By present-day standards, the methods of selection would seem simplistic because selection was based only on the phenotype of individual plants. But the selection methods were effective to develop landrace cultivars that provided substance for the local settlements to prosper and expand into regional civilizations. The landrace cultivars also were the germplasm resources for future generations of plant breeding. The original plant breeders, therefore, provided the plant resources for the development of human societies and the germplasm resources to sustain modern human societies. The major contributions of the early plant breeders were to develop domesticated crop species, dependent on humans (in some instances for survival) from their wild progenitors.

Domestication of our major crop species from their wild progenitors occurred over broad areas and time frames. The extent and rapidity of the distribution of the different domesticated crops depended on human movements within and among different areas of the world. It is estimated, for example, that maize (Zea mays L.) was domesticated 7,000-10,000 years ago in southern Mexico and Guatemala. Maize, however, was unknown outside the Western Hemisphere until Columbus 
(1493) brought maize seed upon his return to Europe. The potential of maize was recognized and spread rapidly throughout the world. Similar patterns occurred for the other domesticated crop species. Because of the different needs of the different societies and the different environments inhabited, the next stage of plant breeding occurred. The selection techniques of the domesticators were used to develop cultivars adapted to their specific environments. Within the domesticated crop species, different landraces were developed that had the desired traits for the local needs and customs and environmental conditions. By 1900, it was reported, for example, that more than 800 distinctive open-pollinated cultivars were available in the United States. Until 1900, the plant breeding selection methods emphasized selection of individual phenotypes, but modifications were being made to improve selection effectiveness, such as the progeny test suggested by Vilmorin in 1858. Although the early plant breeders did not have a knowledge of Mendelian genetics (and his predecessors, they did observe that progeny tended to resemble their parents) and scientific methods to separate genetic and environmental effects (i.e., heritability) in trait expression, the early plant breeders were effective in domestication of wild, weedy plants for human use and the development of improved strains and cultivars that provided the germplasm resources for twentieth century plant breeders.

Plant breeding is often described as the art and science of developing superior cultivars. Art is defined as the skill in performance acquired by experience, study, or observation, which were certainly strong traits of the early plant breeders, whereas science is defined as the knowledge attained through study or practice. The distinctions between art and science are not always clear because even with experimental field and molecular data, subjective decisions are often necessary in choices of parents, progenies to consider for further testing, choices of testers, stage of testing, etc. But the relative importance of the art and science of plant breeding was reversed during the nineteenth and twentieth centuries with the emphasis on science (data driven) replacing emphasis on art (phenotypic appearance). The scientific basis of plant breeding was enhanced in the early part of the twentieth century by several developments, including the rediscovery of Mendel's laws of inheritance; a greater understanding of Darwin's theory of evolution based on Mendelian genetics; development of field experimental methods (randomization, replication, and repetition) to make valid comparisons among cultivars; theoretical basis for the inheritance of complex traits designated as quantitative traits; integration of the concepts of evolution, Mendelian genetics, and quantitative genetics to provide a basis to understand (and predict) response to selection; the importance of recycling of germplasm (both via pedigree selection within crosses of related lines and genetically broad-based populations) to enhance consistent genetic advance; and the advances made during the latter part of the twentieth century in molecular genetics on qualitative trait loci. Each of the developments impacted plant breeding methods in different ways, but collectively, all have been important to provide a firm and valid genetic basis for developing superior cultivars for the producers. Each of the advances was made to give greater emphasis to selection based on genotypic differences. During the past 100 years, plant breeding has changed from 
selection based on individual phenotypes to selection at the DNA level for selection for primarily genetic differences. This trend will continue in the future with greater emphasis at the DNA, gene, and phenotypic levels.

This volume is a summary and an update on the breeding methods that have evolved for our major cereal crop species, especially those based on breeding experience, often not presented in books. Similar to other research disciplines, rapid changes occur annually for the scientific basis of plant breeding. Although the basic genetic information and techniques of plant breeding continue to evolve, the basic concepts of plant breeding to develop superior cultivars remain the same; integrate all the available information to enhance the effectiveness and efficiency of our choice of parental materials, genetic enhancement of germplasm resources, estimate breeding values of progenies with greater levels of precision, and develop genetically diverse cultivars with greater tolerances to pest and environmental stresses as well as greater quality for a healthier diet. There is documented evidence that significant genetic improvements for greater yields have been made in cultivated crop species during the twentieth century. Similar genetic improvements are needed to meet human needs (e.g., biofuels) during the twenty-first century. Genetic information at the DNA level will continue to provide basic scientific information and will, hopefully, have a greater role in the future. Similar to other scientific disciplines, the science of plant breeding will continue to evolve for development of superior cultivars with the necessary traits to continue to provide adequate nutritional food supplies to sustain continued population expansions in a world of finite dimensions. Plant breeders have and will continue to develop cultivars. Plant breeding has and will continue to have important roles to ensure the future health of the world's human societies.

Fargo, ND

Marcelo J. Carena

Ames, IA

Arnel R. Hallauer 


\section{Contents}

\section{Section I Cereal Crop Breeding}

Maize Breeding

Arnel R. Hallauer and Marcelo J. Carena

Rice Breeding

Elcio P. Guimarães

Spring Wheat Breeding

M. Mergoum, P.K. Singh, J.A. Anderson, R. J. Peña, R.P. Singh,

S.S. Xu, and J.K. Ransom

Rye Breeding

H.H. Geiger and T. Miedaner

Grain Sorghum Breeding

Robert G. Henzell and David R. Jordan

Durum Wheat Breeding

Conxita Royo, Elias M. Elias, and Frank A. Manthey

Barley

R.D. Horsley, J.D. Franckowiak, and P.B. Schwarz

Winter and Specialty Wheat

P. Baenziger, R. Graybosch, D. Van Sanford, and W. Berzonsky

Triticale: A "New" Crop with Old Challenges

M. Mergoum, P.K. Singh, R.J. Peña, A.J. Lozano-del Río,

K.V. Cooper, D.F. Salmon, and H. Gómez Macpherson 
Section II Adding Value to Breeding

Statistical Analyses of Genotype by Environment Data

Ignacio Romagosa, Fred A. van Eeuwijk, and William T.B. Thomas

Breeding for Quality Traits in Cereals: A Revised Outlook

on Old and New Tools for Integrated Breeding

Lars Munck

Breeding for Silage Quality Traits in Cereals

Y. Barrière, S. Guillaumie, M. Pichon, and J.C. Emile

Participatory Plant Breeding in Cereals

S. Ceccarelli and S. Grando

Index 


\section{Contributors}

\section{J.A. Anderson}

Department of Agronomy and Plant Genetics, University of Minnesota, St. Paul, MN 55108, USA

\section{S. Baezinger}

Department of Agronomy and Horticulture, University of Nebraska-Lincoln, Lincoln, NE 68588, USA

Y. Barrière

Unité de Génétique et d'Amélioration des Plantes Fourragères, INRA, Route de Saintes, BP6, F-86600 Lusignan, France

W. Berzonsky

North Dakota State University, Department of Plant Sciences, NDSU Dept. 7670, Po Box 6050, Fougo, ND 58108-6050

M.J. Carena

North Dakota State University, Department of Plant Sciences, NDSU Dept. 7670, Po Box 6050, Fougo, ND 58108-6050

S. Ceccarelli

The International Center for Agricultural Research in the Dry Areas (ICARDA), Aleppo, Syria

K.V. Cooper

P.O. Box 689, Stirling, SA 5152, Australia

F.A. van Eeuwijk

Wageningen University, Applied Statistics, 6700 AC Wageningen, the Netherlands

E. Elias

North Dakota State University, Department of Plant Sciences, NDSU Dept. 7670, Po Box 6050, Fougo, ND 58108-6050 
J.C. Emile

Unité Expérimentale Fourrages et Environnement, INRA, Les Verrines, F-86600 Lusignan, France

J. Franckowiak

Department of Primary Industries and Fisheries, Hermitage Research Station, Warwick, Queensland, Australia

H.H. Geiger

University of Hohenheim, Institute of Plant Breeding, Seed Science, and Population Genetics, D-70593 Stuttgart, Germany

S. Grando

The International Center for Agricultural Research in the Dry Areas (ICARDA), Aleppo, Syria

R. Graybosch

USDA-ARS and Department of Agronomy and Horticulture, University of Nebraska-Lincoln, Lincoln, NE 68588, USA

S. Guillaumie

Unité de Génétique et d'Amélioration des Plantes Fourragères, INRA, Route de Saintes, BP6, F-86600 Lusignan, France

E.P. Guimaraes

Food and Agriculture Organization of the United Nations (FAO), Viale delle Termi di Caracalla, Crop and Grassland Service (AGPC), 00153 Rome, Italy
A.R. Hallauer
Department of Agronomy, Iowa State University, Ames, IA 50011, USA
R.G. Henzell
Department of Primary Industries, University of Queensland, Queensland, Australia
R. Horsley
North Dakota State University, Department of Plant Sciences, NDSU Dept. 7670, Po Box 6050, Fougo, ND 58108-6050
D.R. Jordan
Department of Primary Industries, University of Queensland, Queensland, Australia
H. Gómez Macpherson
Instituto de Agricultura Sostenible, CSIC, 14071 Córdoba, Spain 
F.A. Manthey

North Dakota State University, Department of Plant Sciences, NDSU Dept. 7670, Po Box 6050, Fougo, ND 58108-6050

T. Medianer

University of Hobenbeim, State Plant Breeding Institute, D-70593 Stuttgalt, Germany

M. Mergoum

North Dakota State University, Department of Plant Sciences, NDSU Dept. 7670, Po Box 6050, Fougo, ND 58108-6050

L. Munck

Department of Food Science, Quality and Technology, Spectroscopy and Chemometrics Group, University of Copenhagen, Frederiksberg, Denmark

R.J. Peña

Wheat Program, International Maize and Wheat Improvement Center (CIMMYT), Mexico DF 06600, Mexico

M. Pichon

UMR5546, Pôle de Biotechnologie Végétale, 24 chemin de Borde Rouge, BP17, F-31326 Castanet-Tolosan, France

\section{J.K. Ransom}

North Dakota State University, Department of Plant Sciences, NDSU Dept. 7670, Po Box 6050, Fougo, ND 58108-6050

\section{A.J. Lozano del Rio}

UAAAN, Dept. de Fitomejoramiento, Buenavista, Saltillo, Coahuila, Mexico, CP 25315

I. Romagosa

Centre UdL-IRTA, University of Lleida, Lleida, Spain

C. Royo

Institute for Food and Agricultural Research and Technology, Generalitat de Catalunya, Cereal Breeding, Lleida, Spain

D.F. Salmon

Field Crop Development Centre, Alberta Agriculture and Food, 5030-50th Street, Lacombe, AB, T4L 1W9, Canada

D. van Sanford

Department of Plant and Soils Sciences, University of Kentucky, Lexington, KY 40546, USA 
P.B. Schwarz

North Dakota State University, Department of Plant Sciences, NDSU Dept. 7670, Po Box 6050, Fougo, ND 58108-6050

P.K. Singh

North Dakota State University, Department of Plant Sciences, NDSU Dept. 7670, Po Box 6050, Fougo, ND 58108-6050

R.P. Singh

Wheat Program, International Maize and Wheat Improvement Center (CIMMYT), Mexico DF 06600, Mexico

W.T.B. Thomas

Scottish Crops Research Institute, Invergowrie, Dundee, UK

S.S. Xu

USDA-ARS, Northern Crop Science Laboratory, Fargo, ND 58108-6050, USA 